\title{
GAWAI DAN IBU MUDA : STUDI POLA ASUH IBU MUDA PADA ANAK DI DUSUN KARANGANYAR
}

\author{
Mu'adi \\ Mahasiswa STAINU Temanggung
}

\begin{abstract}
Abstrak
Media soaial merupakan sumber informasi yang bisa mengubah segala hal sisikehidupan manusia. Hal ini tidak terlepas dari perkembangan teknologi yang merambah kaum hawa khususnya ibu muda. Dikalangan ibu muda media sosial diangap unggul didalam kecepatan interaksi segala informasi bisa dengan mudah didapatkan. Tidak hanya itu, media sosial juga sebagai ruang khusus untuk para ibu muda berbagi pengalaman. Bahkan tidak sedikit yang kemudian menganggapnya sebagai label kekinian demi menjaga gengsi. Pandangan masyarakat melihat perempuan yang masih didominasi dalam segala hal oleh laki-laki. Buat perempuan media sosial menjadi sarana untuk membuktikan bahwa perempuan bisa mengaktualisasi diri mereka dengan baik. Sehingga ketimpangan sosial terhadap laki-laki bisa teratasi, perempuan yang aktif dalam media sosial dan tidak adanya kontrol secara langsung yang diberikan oleh orang tua, terdapat upaya kontrol yang diberikan dari orang tua. Dalam membatasi perilaku pemain gawai yang tidak sesuai dengan nilai dan norma dimasyarakat.
\end{abstract}

Kata kunci : media sosial, pola asuh, ibu muda

\section{Pendahuluan}

Teknologi informasi ahir-ahir ini perkembangannya begitu pesat. Terutama media Informasi dan komunikasi berbasis teknologi. Internet dan sosial media menjadi dunia baru yang bisa diperlakukan layaknya dunia nyata. Internet dan sosial media merupakan alat utama dalam mengambil segala informasi. Di layar televise, sering kali kita melihat selebriti-selebriti yang punya banyak pengemar melalui sosial media semua merupakan bukti bahwa sosial media menjadi ladang dalam segala hal yang menyangkut kehidupan manusia.

Berdasarkan dalam hasil survai yang dilakukannya mencatat sekitar 132,7 juta orang Indonesia disepanjng 2016 telah terhubung diinternet adapun total penduduk di Indonesia sekitar 256,2 juta orang. Hal ini mengindikasikan kenaikan 51,8 persen. dibanding pada tahun 2014 jumlah pengguna internet dimana survai yang dilakukan APJH pada 2014 hanya terdapat 88 juta pengguna internet.( Departemen komunikasi dan informasi di Indonesia. 2016).

Berdasarkan hasil survai tersebut, dengan berkembangnya sosial media mungkin orang mengunakan media sosial untuk melampiaskan segala sesuatu melalui layanan sosial media dari kehidupan sehari-hari, dagang hingga polotik, namun selain itu sering kali unggahan-unggahan yang ada, sering kali disalah gunakan dan yang sangat menarik ketika sosial media ahir-ahir ini merambah ibu-ibu muda untuk menerapkan pola asuh pada anak melalui internet dan sosial media.

Sementara saat ini penyebaran dan perolehan informasi tentang pola asuh pada anak disosial media sudah sangat meluas. Pergeseran yang sangat signifikan inilah sehingga para ibu muda kini sangat mudah mendapatka dan mengakses informasi bagaimana cara yang baik untuk mengasuh anaknya. Pada zaman dulu ibu muda dalam mengasuh anaknya masih mengandalkan dari orang tuanya, yang dianggap berpengalaman dan sudah mengalami bagaimana pola asuh pada anak yang didapat dari nenek moyang dan turun temurun pada anak-anaknya. Mulai dari mitos-mitos dan cara tradisional tentang larangan berbagaihal yang ada sangkut pautnya dengan pola asuh anak. Sekarang sudah sangat berbeda, bergeser 
hampir sembilah puluh drajad yang dulunya masih tradisional bergeser ke internasional khususnya internet dan sosial media.

Mengakses informasi di dunia internet dan sosial madia sangat mudah apalagi untuk mengakses informasi tentang pola asuh pada anak. Dulu hanya dalam ranah offline namun sekarang sudah merambah kedalam ranah online. Pertukaran informasi tidak lagi dibatasi oleh ruang dan waktu, terbatas bertemunya antara informan dan pencari informasi diwaktu dan tempat yang sama. Semua sangat mungkin terjadi karena perkembangan dunia teknologi dan komunikasi yang semakin luas dan pesat.

Dapat kita ketahui bahwa media sosial adalah adalah sebuah media online dengan para pengunanya bisa dengan mudah berpartisipasi, berbagi, dan menciptakan isi meliputi blog, jejaring sosial, wiki, forum dan dunia firtual

Secara Bahasa pola asuh terdiri dari dua kata yaitu pola dan asuh. Menurut kamus umum Bahasa Indonesia, kata polaberarti model, sistem, cara kerja, bentuk (stuktur yang tetap) sedangkan kata asuh mengandung kata menjaga, merawat mendidik anak agar dapat berdiri sendiri. orang tua yang mendapatkan pola asuh permisif memperlihatkan cici-ciri sebagai berikut : orang tua cenderung memberi kebebasan penuh kepada anak tanpa ada batasan dan aturan dari orang tua, tidak adanya hadiah atau pun pujian meski anak berprilaku sosial baik tidak adanya hukuman meski anak melanggar aturan. Hurlock, Elisabeth (2006:72)

Keluarga merupaka Lembaga pertama dalam kehidupan anak, tempat anak belajar, dan menyatakan diri sebagai mahluk social dalam keluarga anak ada hubungan interaksi yang kuat. Memberikan dasar pembentukan tingkah laku, watak,moral,Pendidikan anak. Effendy (1998:53)

Peran dan tanggung jawab seorang ibu adalah menjaga dan memelihara kesehatan angota keluarganya.hal tersebut terdapat dalam fiman Allah SWT yang artinta " kewajiban seorang ibu untuk menyusukan anak-anaknya selama dua tahun dan kewajiban ayah memberi makan dan pakaian kepada para ibu dengan cara yang makruf. Sesungguhnya seseorang tidak dibebani melainkan menurut kadar kesanggupannya” (QS. Al Baqoroh :233)

Peran ibu sebagai kemampuan untuk mengasuh, memdidik dan menentukan nilai kepribadian anaknya. Peran ibu dalam keluarga sangat penting dapat diartikan bahwa kesuksesan dan kebahagiaan keluarga sangat ditentukan oleh peran ibu. Dapat dipastikan seorang ibu yang baik akan baik pula keluarganya dan ibu yang tidak baik akan hancur keluarganya. Sebagian perempuan khususnya ibu muda sangat mengemari social media untuk menjalani kehidupan sehari-hari khususnya dalam mengelola keluarganya.

Dalam penelitian ini ibu muda yang dimaksud adalah wanita yang berusia antara 20 hingga 35 tahun.yang telah menyandang status ibu. Ibu muda yang masuk dalam kategori penelitian atau informan dalam penelitian ini adalah mereka yang sering menghabiskan waktu kesehariannya di sosial media dan sering eksis di facebook khususnya ibu muda di Dusun karanganyar, Desa Gentan, kecamatan Kranggan, Kabupaten temanggung. penelitian ini bertujuan untuk mengetahui pengunaan social media sebagai media pola asuh. ibu muda terhadap anaknya..

\section{Metode penelitian}

Penelitian ini mengunakan metode penelitian kualitatif dengan pendekatan fenomenologi. Dengan penelitian fenomenologi mulai dari menelaah fenomene yang akan diteliti. Fenomenologi berusaha untuk memahami bagaiamana seorang memberi makna pada sebuah pengalaman yang dilakoni. Engkus Kuswarno.(2009:25). Pada penelitian ini pemahaman ibu muda dalam menjalani pola asuh anak yang secara langsung dilakukan oleh informan. 
Data-data yang diperlukan dalam penelitian ini adalah wawancara dan analisis data dari berbagai sumber yang ada kaitanya dengan penelitian ini. Penelitian yang dilakukan ini mewawancarai dari 5 informan yaitu ibu muda yang eksis di dunia maya Selanjudnya analisis data dilakukan dengan cara mengklasifikasikan serta mencari keterkaitan antara data yang satu dengan data yang lainnya semua diperlukan agar data ini dapat disajikan secara urut dan tepat, sehingga keterkaitan data tersebut intinya digunakan untuk menarik kesimpulan yang ditemukan.

\section{Hasil dan pembahasan}

Berdasarkan hasil penelitian dari lima ibu muda yang ada di dusun karang anyar. dapat dipastikan tiga orang mengunakan sosial media sebagai perantara untuk mencari informasi tentang pola asuh pada anak-anaknya. Sisanya dari dua orang memang mengunakan sosial media tidak untuk mencari informasi tentang pola asuh. Social media yang digunakan informan untuk mencari informasi atau media partner karena media tersebut sebagai sumber atau media dalam proses pola asuh.

Mungkin orang mengunakan media sosial untuk melampiaskan segala sesuatu melalui layanan sosial media dari kehidupan sehari-hari, dagang hingga polotik, namun selain itu sering kali unggahan-unggahan yang ada, sering kali disalah gunakan. Kantor pusat Facebook yang ada di Amerika Serikat yang diluncurkan pada bulan februari 2004 hingga September 2012. Facebook memiliki lebih dari satu miliar penguna aktif, lebih dari separuhnya menggunakan telepon gengam. Tiga meliar orang sekitar $40 \%$ populasi dunia, mengunakan media sosial dan menurut sejumlah laporan, kita menghabiskan rata-rata dua jam setiap hari untuk membagikan, menyukai, menulis cuitan dan memperbaharui perangkat facebook. Artinya sekitar setengah juta cuitan dan foto dibagikan setiap menit.

Tingginya angka penguna dan tingginya aktifitas percakapan ataupun pemberitaan di sosial media. Menjadi sangat efektif untuk penyebaran informasi dan diskusi. Mereka yang sulit mendapat informasi secara offline dapat menggunakan media social untuk berinteraksi dengan para ibu lainya. Lebih dari itu mereka dapat menggungkapkan pendapat dan curhat berkaitan dengan aktifitas pola asuh pada anak. Social media telah bmemfasilitasi para pengunanya untuk berinteraksi secara online yang akan mempengaruhi realitas mereka di dunia nyata.

Penelitian ini akan mengungkapkan adanya peringkat yang ada dalam social media yang dipilih oleh informan. Dari berbagai social media yang paling banyak digunakan informan yaitu media online Facebook. Media ini memiliki peringkat tertinggi diantara media lainnya. Hal tersebut adalah bukti nyata adanya kebutuhan informasi yang perlu dipenuhi oleh informan. Melalui soaial media facebook informan dapat mendapat informasi dari ibu muda lainnya yang sama-sama sedang mencari informasi seputar pola asuh anak dan bertukar pengalaman tentang proses pengasuhan. Kebutuhan ini merupakan kebutuhan social yang tidak dapat terlepas dari sifat manusia sebagai mahluk sosial.

Banyak para ahli atau pakar dibidang pola asuh yang sengaja membuat akun di social media dengan tujuan menyebar informasi mengenai pola asuh. Dan banyak juga para ahli pengasuhan merespon pertanyaan para pengikut akunnya. Berdasar hasil penelitian dapat diketahui bahwa telah terjadi pergeseran sumber informasi terhadap nilai-nilai pola asuh yang dilakukan oleh beberapa ibu muda. Pada zaman dulu ibu muda dalam mengasuh anaknya masih mengandalkan dari orang tuanya, yang dianggap berpengalaman dan sudah mengalami bagaimana pola asuh pada anak yang didapat dari nenek moyang dan turun temurun pada anak-anaknya.

Mulai dari mitos-mitos dan cara tradisional tentang larangan berbagaihal yang ada sangkut pautnya dengan pola asuh anak. Sebagai contoh dulu anak dibawah usia lima tahun 
boleh diberi minuman kopi, beberapa tetes kopi untuk meredakan demam anak balita. Dan buat ibu muda yang habis melahirkan biyasanya minum angur merah yang mempunyai kadar alcohol cukup tinggi dengan tujuan agar ibu muda tersebut cepat kembali pulih dan lebih segar setelah melahirkan. Tapi ahir-ahir ini cara-cara tersebut dianggap tidak efektif untuk meredakan demam. Dan sekarang informan mendapatkan informasi dengan cara mengkompres. Berbagai ilmu tersebut di temukan dalam roses interaksi di social media tentang pola asuh pada anak. Berbeda dengan zaman dulu yang mengandalkan orang tua untuk mencari informasi tentang pola asuh. Yang ada sebagai informasi turun temurun dari nenek moyang.

Berdasarkan hasil penelitian para informan atau ibu muda sudah mulai belajar bijak dalam proses pengasuhan anak. Missal dengan cara memberi arahan dan perhatian sang anak kepada hal yang menjadi ketertarikan anak. Cara tersebut dianggap lebih cerdas baik bagi perkembangan motoric ataupun psikomotorik anak.

\section{Motif pengunaan sosial media}

setiap manusia memiliki motif yang menjadi dorongan dan sugesti setiap melakukan tindakan dan setiap pemilihan keputusan. Motif merupakan dorongan, hasrat, keinginan dan tenaga pengerak lainnya yang berasal dari dalam dirinya untuk melakukan sesuatu. Motif dapat dikatakan sebagai kekuatan yang terdapat dalam dirinya memberikan tujuan dan arah kepada tingkah laku seseorang. Sebagai alasan yang mendorong informan mengandalkan social media sebagai media informasi pola asuh terdiri dari dua motif yaitu motif rasional dan motif emosional. Batasan motif rasional dan emosional adalah hal logis yang mendorong informan untuk memilih social media tertentu sebagai media pola asuh. Diantaranya sejumlah jawaban yang di kemukakan oleh informan dari wawancara maupun identifikasi beberapa sumber.

1. Sosial media memungkinkan ibu muda untuk berinteraksi pada ibu muda lainnya.

2. Sosial media dipercaya mampu memberikan informasi terkini tentang pola asuh.

3. Sosial media dapat memberikan informasi yang jelas karena karena tidak hanya bersumber dari satu informasi namun bisa terdiri dari berbagai sumber dari para ahli pemgasuhan anak.

4. Sosial media lebih mudah mengakses informasinya dibanding dengan sumber offline atau orang tua yang terbatas oleh ruang dan waktu.

5. Sosial media memudahkan ibu muda baik yang bekerja dan tidak bekrja untuk bertukar pikiran, pengalaman pola asuh pada anak-anak mereka.

Sementara itu pada informan lainya juga ditemukan dorongan lain untuk mengunaka sosial media yang menghasilkan motif emosional.

1. Alasan yang paling utama alasanya tidak mau di sebut ketinggalan jaman.

2. Alasan mencurahkan isi hati atas keluhan yang ada pada kuluarganya.

3. Alasan sebagai media eksistensi ibu muda masa kini.

Berdasarkan kedua kelompok diatas dapat disimpulkan bahwa motif yang melatarbelakangi informan dalam mengunakan sosial media sebagai media pola asuh sangat banyak bermanfaat dan sangat dipengaruhi oleh faktor psikologis yang ada kaitannya dengan konsep diri. Konsep diri ada dua hal yaitu citra diri (self image) dan harga diri (self esteem). Citra diri berkaitan dengan faktor kognitif individu sedangkan harga diri berhubungan dengan faktor efektif individu. Jallaludin Rahmat (2005:100). Berdasarkan pernyataan diatas dapat ditarik kesimpulan bahwa dalam penelitian ini yang disebut oleh peneliti sebagai motif rasional berbanding lurus dengan citra diri (self image) sedangkan motif emosional berbanding lurus dengan harga diri (self esteem) seperti berikut :

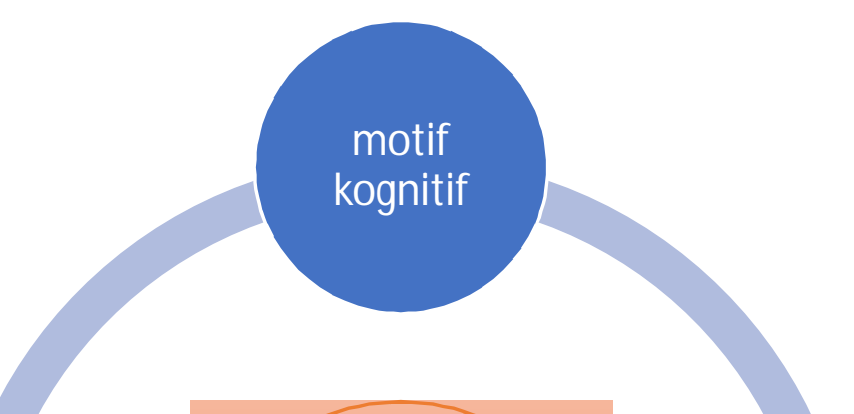




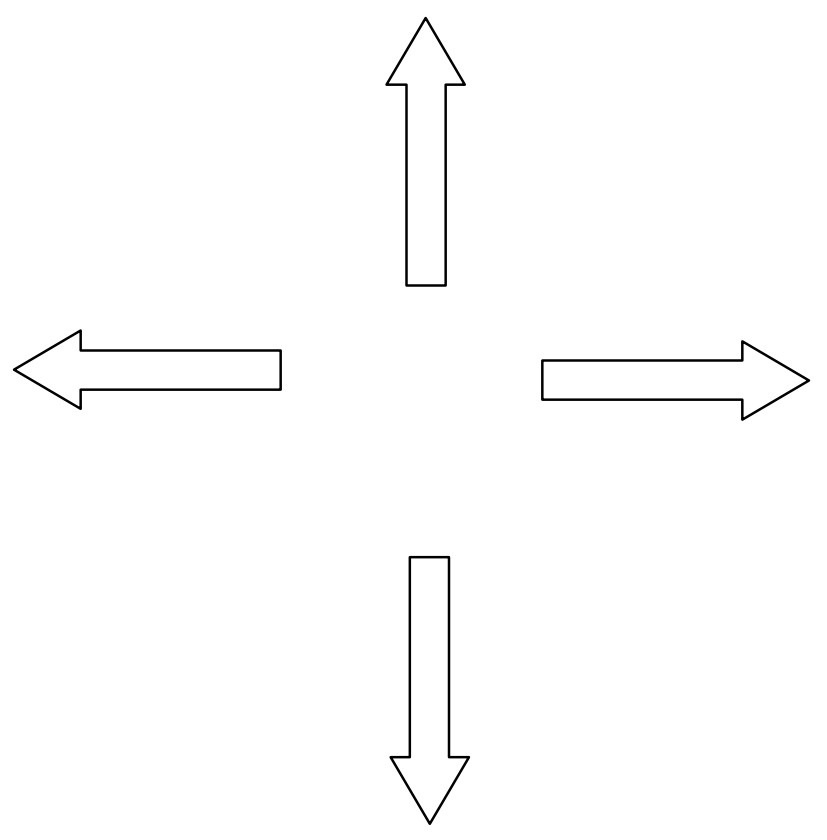

Grafik diatas menunjukkan bahwa terdapat motif yang menjadi dorongan pada informan. Motif yang muncul dari hasilpenelitian ini adalah motif rasional dengan motif emosional. Motif rasional adalah motif berupa hasil pola pikir informan terhadap nilai-nilai logis yang sama dengan motif kognitif. Informan juga memiliki dorongan lain yang masuk dalam kategori motif emosionalyaitu dorongan yang muncul sebagai bentuk emosional selaras dengan motif harga diri. Pada saat informan mengemukakan alasan bahwa dirinya memilih sosial media sebagai media perantara pola asuh karena sosial media mampu memberikan informasi terkini tentang pola asuh anak, maka hal itu masuk dalam kategori rasional. Namun pada saat yang sam informan juga merasa gengsi jika disebut kurang kekinian dan ketinggalan jaman. Maka hal ini masuk kedalam motif emosional.

\section{Kesimpulan}

Mungkin orang mengunakan media sosial untuk melampiaskan segala sesuatu melalui layanan sosial media dari kehidupan sehari-hari, dagang hingga polotik, namun selain itu sering kali unggahan-unggahan yang ada, sering kali disalah gunakan. Dan para ibu muda sebagai ibu yang menunjukkan betapa pentingnya pola asuh anak. Hingga ibu muda mencari informasi dari social media, ada dua motif yang mendorong informan mengunakan social media sebagai media pola asuh yaitu motif rasional dan motif emosional. Dan dari berbagai jenis social media yang paling sering digunakan mencari informasi yaitu Facebook.

informan mendapatkan informasi dengan cara mengkompres. Berbagai ilmu tersebut di temukan dalam roses interaksi di social media tentang pola asuh pada anak. Berbeda dengan zaman dulu yang mengandalkan orang tua untuk mencari informasi tentang pola asuh. Yang ada sebagai informasi turun temurun dari nenek moyang.

Dalam penelitian ini. Berhati-hatilah buat ibu muda saat mengunakan sosial media, berbijaklah mengunakan kata-kata dan mencari berbagai sumber informasi, tetaplah menjujung nilai kesopanan, dan menghargai seseorang. Karena dunia maya khususnya Facebook merupakan dunia kedua setiap orang. Jangan sampai apa yang kita dapat malah akan menjrumuskan para ibu muda kedalam hal yang buruk. 


\section{DAFTAR PUSTAKA}

Rahmad, Jallaludin. 2005. Psikologi : Komunikasi cetakan ke16. Bandung: Remaja rosdakarya.

Hurlock, Elisabeth. 2006. Psikologi Perkembangan cetakan ke5. Jakarta: Erlangga.

Kantor pusat Facebook di Amerika Serikat

Effendi. 1998. Dasar-dasar Keperawatan Kesehatan Masyarakat edisi ke2. Jakarta: EGC

Kuswarno, Engkus. 2009. Fenomenologi (Konsepsi Pedoman Dan Contoh Penelitian). Bandung: Widya Padjajaran.

Quran Surat. Al Baqoroh :233. 